\title{
Gelişmeleri Kaçırma Korkusunun Sosyal Medya Tutumları Üzerine Etkisi
}

\author{
The Effects of Fear of Missing Out Developments on Social Media Attitudes \\ Plnar ERDO $\breve{G} A N^{*}$ \\ Yasemin ŞANLI $^{* *}$
}

$\ddot{O} Z$

Bu çalı̧̧mada üniversite öğrencilerinin gelişmeleri kaçırma korkularının sosyal medyaya yönelik tutumları üzerindeki etkisi araştırılmıştır. Araştırmanın evrenini 2018-2019 eğitim-öğretim döneminde öğrenim gören Karamanoğlu Mehmetbey Üniversitesi, Sağllk Bilimleri Fakültesi öğrencileri oluşturmaktadır. Araştırmada, üniversite ögrrencilerinin gelişmeleri kaçırma korkuları ile sosyal medya tutumları arasındaki ilişkinin anlamlı olduğu ve geliş̧meleri kaçırma korkusu ile sosyal medya tutumları arasında pozitif yönde ilişki olduğu bulgulanmıştır Sosyal medya tutum ölçeğinin alt boyutlarından olan paylaşım ihtiyacı, sosyal yetkinlik ve ögretim görevlileriyle iletişim ile gelişmeleri kaçırma korkusu arasında pozitif yönde anlaml iliş̧ki, sosyal izolasyon ile gelişmeleri kaçırma korkusu arasında negatif iliş̧ki bulgulanmıştır. Yapılan regresyon analizi sonucunda da gelişmeleri kaçırma korkusunun paylaşım ihtiyacı, sosyal yetkinlik, ögrretim görevlileriyle iletişim ve sosyal izolasyon boyutlarını anlamlı şekilde etkilediği bulgulanmıştır.

\section{ANAHTAR KELIMELER}

Gelişmeleri Kaçırma Korkusu, Sosyal Medya Tutumlarl,

\begin{abstract}
In this study, the effects of university students' fear of missing out (FoMO) and their attitudes towards social media were studied. The population of the research consists of the students of the Faculty of Health Sciences of Karamanoglu Mehmetbey University, who were educated in the 2018-2019 academic year. In the study, it was found that the relationship between university students' fear of missing out developments and social media attitudes were statistically significant and there was a positive relationship between fear of missing out developments and social media attitudes. The need for sharing, which is one of the sub-dimensions of social media attitude scale, social competence and a positive meaningful relationship was found between communication with teachers and fear of missing developments, and negative correlation was found between social isolation and fear of missing developments. As a result of the regression analysis, it was found that the fear of missing the developments significantly affected the need for sharing, social competence, communication with instructors and social isolation.
\end{abstract}

\section{KEYWORDS}

Fear of MissingOut (FoMO), Social Media Attitudes

\begin{tabular}{|c|c|c|}
\hline & $\begin{array}{c}\text { Makale Geliş Tarihi / SubmissionDate } \\
\text { 30.07.2019 }\end{array}$ & $\begin{array}{c}\text { Makale Kabul Tarihi / Date of Acceptance } \\
\text { 07.11.2019 }\end{array}$ \\
\hline Attf & $\begin{array}{l}\text { Erdoğan, P. ve Şanlı, Y. (2019).G } \\
\text { SelçukÜniversitesi Sosyal Bilimler Me. }\end{array}$ & $\begin{array}{l}\text { rkusunun Sosyal Medya Tutumları Üzerine Etkisi. } \\
22(2), 615-627 \text {. }\end{array}$ \\
\hline
\end{tabular}

\footnotetext{
*Dr.Öğr. Üyesi, Karamanoğlu MehmetbeyÜniversitesi,Uygulamalı Bilimler Yüksekokulu, pinarerdogan@kmu.edu.tr, ORCID: 0000-0000-7817-1342

${ }^{* * *}$ Dr.Öğr. Üyesi, Karamanoğlu MehmetbeyÜniversitesi, Sağlık Bilimleri Fakültesi, yaseminsanli@kmu.edu.tr, ORCID: 0000-0001-9169-0577
} 


\section{GİRIŞ}

World Wide Web'in 1991 yılında kullanılmasıyla birlikte geleneksel medya kavramı radikal bir değişime uğramıştır. Bu değişimin ana nedenlerinden biri insanların sadece okuyucu oldukları web 1'den, kullanıcıların diğer kullanıcılarla ağ ile iletişim kurmasına izin veren "okunabilir ve yazılabilir web"şeklinde belirtilen web 2'nin gelişimidir (D'souza, 2006: 8; Ergenç, 2011:18; Büyükșener, 2009:19). İletişim ve paylaşıma izin veren sosyal medya, web 2'nin gelişimiyle birlikte doğmuştur (Mavnacioğlu, 2009:63; Newson, Houghton ve Patten, 2008:138).

Sosyal medya ilk kez 2006 y1lında Chris Shipley tarafından kullanılmış (Boyd ve Ellison, 2007: 214; Newson, Houghton ve Patten, 2008: 49; Wenting,2019; 15) ve "bilgi alışverişi, katılım ve işbirliğini destekleyen bir dizi çevrimiçi araç ve uygulama" olarak tanımlanmıştır (Wenting, 2019:15). Kavram ilk kez 2006 yılında kullanılsa da ilk çağdaş sosyal medya uygulaması olan Sixdegrees Sitesi 1997 yılında (Sayın, Armağan ve Karakulle, 2017: 440) Friendster ve Myspace 2002-2003, Flickr ve Youtube 2004-2005 Facebook ve Twitter ise 2006-2007 yıllarında paylaşıma açılmışlardır (Otrar ve Argın, 2015:392).

Sosyal medyanın tanımı genellikle farklı şekillerde ancak benzer çerçevede yapılmıştır. The MerriamWebster sözlüğü (www.merriam-webster.com) sosyal medyayı, "kullanıcıların bilgi, fikir, kişisel mesaj ve diğer içerikleri (videolar gibi) paylaşmak için çevrim içi topluluklar oluşturduğu elektronik iletişim biçimleri" şeklinde tanımlamıştır. Bir diğer tanımda sosyal medya "zaman ve mekân sınırlaması olmadan (mobil tabanlı), paylaşımın, tartışmanın esas olduğu insanî bir iletişim şekli " olarak tanımlanmıştır (Vural ve Bat, 2010:3351). "Kullanıcıların bir sistem dahilinde profil oluşturup, başka kullanıcıların sistemdeki listelenmiş bağlantılarını görüp ve aralarında gezmesine izin veren web tabanlı hizmetlerin tümüne sosyal ağ (Büyükşener, 2009:19), sosyal ağları (Facebook, Bloglar, Youtube gibi) içine alan platformlara da sosyal medya denilmektedir (Büyükşsener, 2009:19).

İnsanlara bilgi edinme, yayınlama ve paylaşma yolları sunmakta olan (Wenting, 2019:15) sosyal medyanın temelini, kullanıcıların ürettiği içerikler oluşturmaktadır (Büyükşener, 2009:22). Mayfield (2008:5) sosyal medyayı katılım, açıklık, konuşma, toplum ve bağlantılılık özelliklerinin bütünü olarak belirtmiştir (Mayfield ; 2008:5). Katılım; sosyal medyanın, medya ve izleyici arasındaki çizgiyi bulanıklaştırarak ilgili herkesin katkı ve geri bildirimini teşvik etmesi olarak belirtilirken, açıklık; sosyal medyada içeriğe erişim ve içerik kullanımında bir engel bulunmaması ve bildirimlere ve katılımlara açık olması şeklinde ifade edilmiştir. Konuşma; iki yönlü konuşmaya izin vermesi, toplum; toplulukların hızlı bir şekilde oluşturularak etkili bir şekilde iletişim kurmasını sağlaması ve son olarak bağlllık ise; sosyal medyanın birbirleriyle olan bağlantılarını kullanarak, birbirleriyle olan bağlantılarını geliştirmesidir (Mayfield; 2008:5) şeklinde ifade edilmiştir. Sosyal içerikli web sitelerinden oluşan sosyal medya (Ada ve Akın, 2015)' nın Mayfield (2008:6) tarafından belirtilen toplam 7 çeşidi bulunmaktadır. Bunlar;

Sosyal ağlar: Bireylerin web sayfası oluşturmasına ve içerik paylaşımı için diğer insanlarla iletişim kurmasına izin veren sosyal medya çeşididir (örn.Facebook).

Bloglar: En son ilk haberin göründüğü çevrimiçi dergilerdir

Vikiler: İnsanların ortak bir belge veya veritabanı görevi görerek, kendilerine bilgi eklenmesine ve düzenlenmesineizin verir. (örn:Wikipedia).

Podcast: Abonelikle erişilebilen ses ve video dosyalarının bulunduğu sosyal medya çeşididir.

Forum: Çevrimiçi tartışma alanlarıdır

İçerik toplulukları: Sınırları belirlenmiş çeşitlilikteki içeriği düzenleyip paylaşan topluluklar (örn.Youtube).

Mikrobloglar: Miktarı düşük içeriğin çevrimiçi ve mobil telefon ağı ile dağıtıldığı sosyal ağlardır (örn.Twitter).

Sürekli güncellenebilmesi ve çoklu kullanım ve sanal paylaşım imkanlarıyla en ideal iletişim alanı olarak görülmeye başlanan sosyal medya (Vural ve Bat, 2010:3349 ), internet kullanımının yaygınlaşmasıyla başlamış ve insanlar arasındaki iletişim şeklini değiştirmiştir (Edosomwan vd., 2011:2-4). Nitekim "We Are Social"in yayınlamış olduğu "Digital in 2019" raporu bunu doğrular niteliktedir. Rapora göre 2018 yılında dünya nüfusunun \%56's1 internet kullanıcısı, \% 45'i ise sosyal medya kullanıcıs1 durumundadır. İnternet kullanımı en yüksek 25-44 yaş arası gruba (\%29) aitken bu oranı \%22 ile 0-12 yaş 
arası takip etmektedir. Sosyal medya kullanımı 2018 yılı istatistiklerine göre, 2.27 milyar kullanıcı sayısı ile Facebook dünyada ilk sırada bulunurken, ikinci sırada 1,90 milyar kullanıcı ile Youtube bulunmaktadır (we are socila). Sosyal medya kullanımı özellikle gençler arasında daha yüksektir (Li, Bernoff, Pflaum ve Glass, 2007). Dünya çapında işletme, pazarlama ve teknoloji konularını analiz etmek için araştırmalar yapan Forrester (Forrester.com) çevrimiçi tüketici davranışlarını takip etmek amacıyla hem yetişkinlerin hem de gençlerin sosyal ağ kullanımı ile ilgili çalışmalar yapmıştır (Li vd. 2007:2). Bu çalışma bulgularına göre - gençlerin yaklaşık \% 60'1 (12-17 yaş arası) ve genç yetişkinlerin \% 80'i (18-21 yaş arası) sosyal paylaşım sitelerini kullanmakta ve gençlerin $\% 60^{\prime}$ ', genç yetişkinlerin $\%$ 67'si her gün veya daha fazla bu siteleri ziyaret etmektedir. Yetişkinlerin ise \% 30'u (18+) sosyal paylaşım sitelerini kullanmaktadır (Li vd., 2007:2). Benzer bir araştırma Türkiye'de yapılmıştır. Ulaştırma Bakanlığı bünyesinde bulunan internet kurulu tarafından, ODTÜ (Ortadoğu Teknik Üniversitesi) ile Bilgi Teknolojileri ve İletişim Kurumu Telekomünikasyon İletişim Başkanlığı'nın destekleriyle yapılan“Çocukların Sosyal Paylaşım Sitelerini Kullanım Alışkanlıkları Araştırması Raporu” (2011:1)'na göre çocukların neredeyse \%70'i gün içinde en az bir kez internet kullanmakta, internet kullanan bu çocukların \% 66'sı ise gün içinde az bir kere sosyal ağları kullanıp ve sosyal medyada ortalama 72 dakika zaman geçirmektedir. En fazla kullanılan sosyal ağ \%99'luk kulanım oranıyla Facebook' dur. Facebook'un en yoğun kullanım amaçları ise Smock vd. (2011: 2322) tarafından rahatlatıcı eğlence, etkileyici bilgi paylaşımı ve sosyal etkileşim olarak bulgulanmıştır.

Farklı amaçlarla kullanılan sosyal medyanın (sosyalleşme, kaçış, bilgilenme, eğlenme, iletişim, vakit geçirme) (Hazar, 2011:151) kullanıcı sayısı ve kullanım süresi her geçen gün katlanarak artmaktadır. Bu artış, yapılan pek çok çalışmada görüldüğü üzere beraberinde pek çok değişim ve etkiyi getirmektedir. Işıktaş (2016)'ın üniversite öğrencileri örneklemi kullanarak yaptı̆̆ 1 çalışmada öğrenciler, iletişim, sosyalleşme, haberleşme, paylaşım, kendini ifade etme ve psikolojik rahatlamayı sosyal medyanın olumlu etkileri olarak, gereğinden fazla zaman harcama, ders verimliliğini düşürme, ilginin dağılması, sosyalleşmeyi engelleme şeklinde de olumsuz etkiler olarak belirtmişlerdir (Işıktaş; 2016:573). "Çocukların Sosyal Paylaşım Sitelerini Kullanım Alışkanlıkları Araştırması Raporu” (2011:11)'nda ise çocukların \% 62'si sosyal medyanın kendilerini olumsuz etkilemediğini belirtmişlerdir. Olumsuz etkilediğini belirten \%36'lık grup ise bu etkileri; derslerine yeterince zaman ayıramama (\%60), arkadaşlarına yeterince zaman ayıramama (\%24), ailesine yeterince zaman ayıramama (\%21), yaşına uygun olmayan bilgi ve içerikle karşılaşma (\%17), sosyal etkinliklere yeterince zaman ayıramama (\%10) olarak belirtmişlerdir. Yeniçıktı (2016) 927 kişi ile yaptığı çalışmasında sosyal medya kullanım amaçlarını, sohbet etme, zaman geçirme ve bilgi kaynaklarına erişim şeklinde bulgularken en çok kullanılan sosyal medya Facebook'un kullanım amaçlarını bilgi verme, bilgi alma, iletişim/sosyallik, bağlantı kurma/gözlem, eğlenme/vakit geçirme ve merak olarak bulgulamıştır ve dikkat çeken bir araştırma bulgusu araştırmaya katılan katılımcıların günlük ortalama 3 saat sosyal medyada vakit geçirmeleridir.

Bireyler arasında artan sosyal medya kullanımını bağımlılık olarak niteleyen Beyens vd. (2016:1), bu bağımlılığın nedenini bireylerin sosyal ihtiyaçlarını tatmin etme istekleri, istikrarlı kişiler arası ilişkiler kurma ve sürdürme ihtiyac1, popülerliğe duyulan ihtiyaç olarak belirtmektedir.

Sosyal medya kullanımını tetikleyen bir diğer etken ise 2013 yılında Oxford sözlüğüne giren (Ulaştıran, 2017) FoMO (Fear Of MissingOut) yani kaçırma korkusudur (Przybylski vd., 2013:1841). Sürekli kaçırma korkusu yaşayan bireylerde çok fazla sosyal katılımı vadeden sosyal medya katılımı çekici gelebilmektedir (Przybylski vd., 2013:1841).

Bireylerin sosyal olarak dışlanma korkuları sonucu oluşan FoMO (Blackwell, 2017:69) "başkalarının kendisi yokken güzel bir deneyimi yaşabileceğine dair endişe" (Przybylski vd., 2013:1841) "heyecan verici ya da ilginç bir olayın şu anda başka bir yerde gerçekleşebileceği endişesi” (Oxford Sözlük) olarak tanımlanmakta ve kişilerin bir şeyi kaçırmamak için sürekli sosyal medya üzerinden iletişim kurmalarıyla sonuçlanmaktadır (Wiesner, 2017:5; Oberst, 2017). Bireylerin bir gruba ait olma ihtiyacından doğan FoMO'nun giderilmesinde sosyal medya çok etkin rol oynamaktadır (Wiesner, 2017:5).

Yüksek etkileşim, sürekli bağlantı ve düşük düzey anlaşmazlık özellikleriyle sosyal medyaya yönelmek, kaçırma korkusu yüksek olan bireyler için önemli nedenlerdir (Przybylski vd., 2013:1841). Yapılan çalışmalarda bu yönelimi doğrular niteliktedir (Oberst, 2017; Blackwell, 2017; Beyens, 2016; Alt, 2015; Przybylski vd., 2013;). Przybylski vd.( 2013) çalışmalarında FoMO’yu sosyal medya katılımıyla güçlü bir şekilde bağlantılı bulmuş, sosyal medya etkileşimine aracılık ettiği ve ders sırasında sosyal medya kullanımını etkilediğini bulgulamışlardır. Facebook kullanımı FoMO ilişkisinin araştırıldığı çalışmada (Beyens, 2016), FoMO'su yüksek ergenlerin daha yoğun Facebook kullandıkları, Facebook'ta popüler 
olmadıklarında daha fazla stres yaşadıkları ve çevrimiçi olmadıklarında daha fazla stres yaşadıkları bulgulanmıştır. $\mathrm{Bu}$ çalışma bulgularına dayanarak bu çalışma üniversite öğrencilerinin FoMO düzeylerinin sosyal medya tutumlarına etkisini araştırmayı amaçlamıştır. Üniversite öğrencisi örneklemi kullanılarak yaptığı çalışmada Alt (2017) üniversitede farklı dinlere sahip öğrencilerin FoMO düzeyleri ile sosyal medya etkileşimleri arasında farklılık aradığı çalışmasında özellikle azınlık öğrencilerin ders esnasında daha çok sosyal medya kullandıklarını ve FoMO düzeylerinin daha yüksek olduğunu bulgulamıştır.

Çalışmalar göstermektedir ki sosyal medya etkileşimleri ile FoMO arasında hangisinin neden hangisinin sonuç olduğu belli olmaksızın önemli ilişki bulunmaktadır. Bu amaç doğrultusunda bu çalışmada "üniversite öğrencilerinin gelişmeleri kaçırma korkuları sosyal medyaya ilişkin tutumlarını etkileyeceği varsayılarak bu ilişki araştırılmıştır.

\section{ARAŞTIRMA}

\subsection{Araştırmanın Amacı ve Önemi}

Özellikle gençlerin hayatlarının vazgeçilmez bir parçası haline gelen yoğun sosyal medya kullanımının öğrenciler üzerinde büyük etkileri olabileceği düşünülmektedir. Sosyal medya da geçirilen gereğinden fazla zaman, ders verimliliğinde düşme, aileye yeterince zaman ayıramama, uygunsuz içeriklerle karşılaşma ve sosyalleşmeyi engelleme gibi olumsuz etkilere yol açabilmektedir. Sosyal medya katılımı ile yüksek şekilde ilişki olabilecek gelişmeleri kaçırma korkusunun sosyal medya tutumları üzerine etkisinin araştırılması üniversite öğrencilerinin sosyal medya tutumlarına yönlendiren etkenlerin belirlenmesi açısından önem taşımaktadır.

$\mathrm{Bu}$ araştırma üniversite öğrencilerinin gelişmeleri kaçırma korkularının sosyal medya tutumları üzerinde anlamlı bir ilişkisinin olup olmadığını ve varsa etki düzeyini belirleyerek literatüre bu alanda katkı sağlamayı amaçlamaktadır.

\subsection{Araştırma Modeli}

Araştırma için 24.04.2019 tarih ve 22 karar numarası ile etik kurul izni alınmış, veri toplama yöntemi olarak nicel veri toplama yöntemlerinden anket yöntemi (Yazıcıŏlu ve Erdoğan, 2014:93) ve değişkenler arasındaki ilişkinin araştırıldığı bağıntısal araştırma modeli kullanılmıştır (Gurbetoğlu, 2018).

Araştırma kapsamında araştırılacak model şekil 1'de verilmiştir.

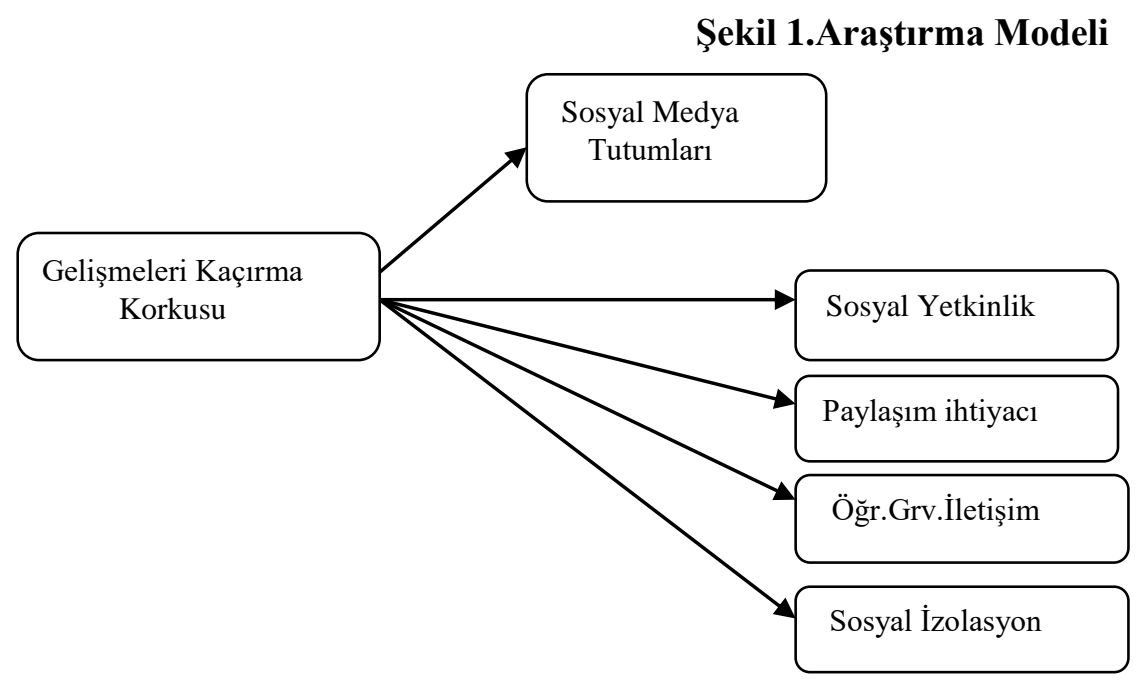

Araştırma modeli çerçevesinde sınanacak hipotezler;

H1: Öğrencilerin gelişmeleri kaçırma korkusu ( FoMO) sosyal medya tutumlarını olumlu etkiler.

H2. Öğrencilerin gelişmeleri kaçırma korkusu ( FoMO) sosyal medya tutumlarının alt boyutlarını olumlu etkiler. 


\subsection{Evren ve Örneklem}

Çalışmanın evrenini Karamanoğlu Mehmetbey Üniversitesi, Sağlık Bilimleri Fakültesi’nde öğrenim gören öğrenciler oluşturmaktadır. 2018-2019 eğitim/öğretim döneminde ilgili fakültede öğrenim gören toplam öğrenci sayısı 450'dir. Çalışmada basit tesadüfi örnekleme yöntemi ile 400 öğrenciye anket formu verilmiş ve toplamda 346 kullanılır anket formuna ulaşılmıştır. Yazıcıŏlu ve Erdoğan $(2014 ; 89) 500$ kişilik bir evren büyüklügünü temsil eden örneklem sayısını 0.05 anlamlılık düzeyinde ve 0.03 örneklem hatasında 341 olarak belirtmiştir. Dolayısıyla örneklem sayımız evreni temsil edecek düzeydedir.

\subsection{Veri Toplama Araçları}

Araştırmada kullanılan 10 sorudan oluşan FoMO ölçeği Przybylski tarafından geliştirilmiş olup, beşli likert tarzı bir ölçektir. Türkçe geçerlilik-güvenirlilik çalışması Gökler vd. (2016) tarafından 200 üniversite öğrencisi örneklemi kullanılarak yapılmıştır. Ölçeğin geçerlilik analizinde AFA'da tek boyutlu bir yap1 ortaya konulmuş ve tek boyutlu bu yapı toplam varyansın \%39.4'ünü açıklamıştır (Gökler vd., 2016:56).

Ölçekteki her soru 1- 5 puan arasında puanlandırılacak olup, alınan puan yükseldikçe "bireyin gelişmeleri kaçırma korkusu yükselmiştir"ş̧eklinde değerlendirilecektir. Gökler vd. (2016:57) Ölçeğin Cronbach Alfa katsayısını 0,81 olarak saptamıştır.

Araştırmada kullanılan sosyal medya tutum ölçeği ise Otrar ve Argın tarafından 13-18 yaş aralığında 302 ortaokul ve lise öğrencisi örneklemi kullanılarak geliştirilen 5'li likert tipi bir ölçektir. Ölçeğin geçerlilik analizinde 23 maddeden oluşan 4 boyutlu bir yapı ortaya konulmuş ve 4 boyutlu yapının toplam varyansın \%56,65'ini açıkladığı belirtilmiştir (Otrar ve Argın, 2015-391-393).

Ölçekte yer alan her madde 1- 5 puan arasında puanlandırılmaktadır. Ölçekten alınan puan arttıkça "bireyin sosyal medya ilgisi" artmaktadır şeklinde değerlendirilecektir. Ölçekte yer alan ters sorular düzeltilerek kodlanmıştır. Otrar ve Argın (2015) ölçeğin cronbach alfa katsayısını 0,85, "paylaşım ihtiyacı boyutu " için 0,80; "sosyal yetkinlik boyutu " için 0,81; "sosyal izolasyon boyutu" için 0,79 ve “öğretmenlerle ilişki boyutu” için 0,81 olarak bulgulamıştır (Otrar ve Argın, 2015-395).

Sosyal yetkinlik boyutu kişinin sosyal medya üzerinden kendini ifade etmesi sonucu yaşadığ 1 yeterlilik hissidir. Paylaşım ihtiyacı boyutu sorulardan yola çıkarak bireylerin sosyal medyada paylaşım yaparak mutlu olmaları durumunu yansıtmaktadır. Öğretim görevlileriyle ilişki boyutu öğrencinin öğretim görevlilerinin kendisini sosyal medyada takip ettiğini düşünüp mutlu olmasıdır. Sosyal izolasyon boyutu ise insanların sosyal medyayı kullanarak kendilerini soyutlayı izole etmesidir.

$\mathrm{Bu}$ çalışmadan elde edilen verilere dayanarak ölçeklerin güvenirlik analizinde kullanılan Alfa Katsayısına bağlı olarak ölçeğin güvenilirliği aşağıdaki gibi yorumlanmıştır (Kayış, 2010: 403):

$$
\begin{array}{ll}
\checkmark & 0,00 \leq \alpha<0,40 \text { arası güvenilir değil. } \\
\checkmark & 0,40 \leq \alpha<0,60 \text { arası güvenilirliği düşük. } \\
\checkmark & 0,60 \leq \alpha<0,80 \text { arası oldukça güvenilir. } \\
\checkmark & 0,80 \leq \alpha<1,00 \text { arası yüksek derecede güvenilir. }
\end{array}
$$

Bu kapsamda ölçeklerin güvenilirlik analizi sonuçları tablo 1'de verilmiştir.

\section{Tablo 1. Ölçeklerin Güvenilirlik Analizi Sonuçları}

\begin{tabular}{l|c|l}
\hline \multicolumn{1}{c|}{ Ölçek } & $\begin{array}{c}\text { Cronbach } \alpha \\
\text { Değeri }\end{array}$ & Sonuç \\
\hline Gelişmeleri Kaçırma Korkusu ( FoMO)Ölçeği & 0,83 & Yüksek derecede güvenilir \\
\hline Sosyal Medya Tutum Ölçeği & 0,76 & Oldukça güvenilir \\
\hline Paylaşım İhtiyacı Boyutu & 0,83 & Yüksek derecede güvenilir \\
\hline Sosyal Yetkinlik Boyutu & 0,83 & Yüksek derecede güvenilir \\
\hline Öğretim Görevlileriyle İletişim Boyutu & 0,79 & Oldukça güvenilir \\
\hline Sosyal İzolasyon Boyutu & 0,79 & Oldukça güvenilir \\
\hline
\end{tabular}

Elde edilen veriler ışığında çalışmada kullandığımız veri toplama araçlarının güvenilir olduğu sonucuna varılmıştır. 


\subsection{Verilerin Analizi}

Araştırma verileri SPSS (22) programından yararlanılarak analiz edilmiştir. Katılımcıların sosyodemografik bilgilerine ilişkin dağılımları ve buna ilişkin frekans ve yüzdeleri verilmiştir. Araştırmada Pearson korelasyon ve basit doğrusal regresyon analizi kullanılmıştır.

\section{BULGULAR}

\subsection{Demografik Bulgular}

Araştırma kapsamındaki öğrencilerin demografik özelliklerine ait bilgiler tablo 2'de verilmiştir.

Tablo 2. Katılımcıların Demografik Özellikleri

\begin{tabular}{c|l|c|c}
\hline \multicolumn{1}{c|}{ Özellikler } & \multicolumn{1}{|c|}{ Değişkenler } & $F$ & $\%$ \\
\hline \multirow{2}{*}{ Cinsiyet } & Kadın & 279 & 80,6 \\
& Erkek & 67 & 19,4 \\
\hline \multirow{5}{*}{ Yaş } & 18 Yaş & 35 & 10,1 \\
& 19 Yaş & 72 & 20,8 \\
& 20 Yaş & 82 & 23,7 \\
& 21 Yaş & 73 & 21,1 \\
& 22 Yaş & 46 & 13,3 \\
& 23 Yaş & 24 & 6,9 \\
& 24 Yaş ve Üzeri & 14 & 4,1 \\
\hline \multirow{5}{*}{ Okuduğu Sinıff } & 1.Sinıf & 157 & 45,4 \\
& 2.Sinıf & 75 & 21,7 \\
& 3.Sinıf & 60 & 17,3 \\
& 4.Sinıf & 54 & 15,6 \\
\hline \multirow{5}{*}{ Okuduğu Bölüm } & Hemşirelik & 258 & 74,6 \\
& Sağlı Yönetimi & 41 & 11,8 \\
& Besl. veDiete. & 47 & 13,6 \\
\hline \multirow{5}{*}{ Yaşanılan Yer } & Aile Yanı & 50 & 14,5 \\
& Yurt & 270 & 78,0 \\
& Arkadaşlarla Evde & 15 & 4,3 \\
& Akraba Yanı & & 4,2 \\
& Evde Tek & 7 & 2,0 \\
\hline
\end{tabular}

Tablo 2'ye göre katılımcıların çoğunluğu $(\% 80,6)$ kadındır. Katılımcıların yaş dağılımları değerlendirildiğinde en büyük çoğunluk 20 yaş $(\% 23,7)$ grubuna ait olsa da, 21 yaş $(\% 21,1)$ ve 19 yaş $(20,8)$ grubunun katılımcı sayıları birbirine oldukça yakındır. Katılımcıların \% 45,4'ü 1. sınıf öğrencisi ve \%74,6'sı hemşirelik bölümü öğrencisi olarak karşımıza çıkmaktadır. Son olarak öğrencilerini \%78'i yurtta kalarak eğitim hayatına devam etmektedir.

\subsection{Korelasyon ve Regresyon Analizi Sonuçları}

Bağımsız değişkenimiz olan gelişmeleri kaçırma korkusunun sosyal medya tutumu ile arasında doğrusal bir ilişki olup olmadığı, varsa bu ilişkinin derecesini belirlemek için "Pearson Korelasyon Analizi" yapılmıştır. Korelasyon analizinde amaç; bağımsız değişken değiştiğinde bağımlı değişkenin ne yönde değişeceğini görmektir (Sungur, 2010:115). Değişkenlerin sürekli olması ve normal dağılmaları korelasyon analizi yapabilmek için gereklidir (Sungur, 2010:115). FoMO ölçeğinin çarpıklık değeri (-,269), basıklık değeri $(-, 229)$ ve sosyal medya ölçeğinin çarpıklık değeri $(, 070)$, basıklık değeri $(, 316)-1$ ve +1 arasında yer aldığı için verilerin normal dağıldığı varsayılmıştır (Erdoğan ve İraz, 2019:161).

Korelasyon katsayısı " $r$ " ile gösterilir ve 1 ile +1 arasında değer alır. Pearson korelasyon katsayıs1; 0,00-0,25 arası çok zayıf, 0,26-0,49 zayıf ilişki, 0,50-0,69 orta düzey ilişki, 0,70-0,89 yüksek düzey ilişki ve 0,90-1,00 çok yüksek ilişki şeklinde yorumlanacaktır (Sungur, 2010:116).

Tablo 3. FoMO ve Sosyal Medya Tutumları Arasındaki Korelasyon Analizi Sonuçları

\begin{tabular}{cccccc}
\hline $\begin{array}{c}\text { Pearson } \\
\text { Korelasyon } \\
\text { Analizi }\end{array}$ & $\begin{array}{c}\text { Sosyal } \\
\text { Yetkinlik } \\
\text { Boyutu }\end{array}$ & $\begin{array}{c}\text { Paylaşım } \\
\text { İhtiyac1 } \\
\text { Boyutu }\end{array}$ & $\begin{array}{c}\text { Öğretim } \\
\text { Grv.̇̇letişim } \\
\text { Boyutu }\end{array}$ & $\begin{array}{c}\text { Sosyal } \\
\text { İzolasyon } \\
\text { Boyutu }\end{array}$ & SMT \\
\hline FoMO &, $241^{* *}$ &, $294^{* *}$ &, $265^{* *}$ &,$- 110^{* *}$ &, $324^{* *}$ \\
\hline Correlation İs Significant At The 0,01 Level (2-Tailed) & & &
\end{tabular}


Araştırma sonuçlarına göre sağlık hizmetleri fakültesi öğrencilerinin FoMO ile sosyal medya tutumları arasında pozitif anlamlı ve zayıf düzey ilişki bulgulanmıştır $(r=0,324 ; \mathrm{p}<0,01)$. FoMO ile sosyal medya tutumu boyutlarından olan sosyal yetkinlik arasında pozitif anlamlı ve çok zayıf düzey ilişki ( $r=0,241$; $\mathrm{p}<0,01)$, paylaşım ihtiyacı boyutu ile FoMO arasında pozitif anlamlı ve zayıf düzey ilişki $(r=0 ; 294 \mathrm{p}<0,01)$, öğretim görevlileriyle iletişim boyutu ile FoMO arasında pozitif anlamlı ve zayıf düzey ilişki ( $r=0,294$; $\mathrm{p}<0,01)$ ve son olarak sosyal izolasyon boyutu ile FoMO arasında negatif anlamlı ve çok zayıf düzey ilişki $(r=-0,110 ; \mathrm{p}<0,01)$ bulgulanmıştır.

Bir bağımlı değişken ile bir bağımsız değişken arasındaki ilişkilerin açıklanması için basit doğrusal regresyon analizi yapılmıştır. Sonuçlar tablo 4'te sunulmuştur.

\section{Tablo 4. FoMO ve Sosyal Medya Tutumları Arasındaki Regresyon Analizi Sonuçları}

\begin{tabular}{|c|c|c|c|c|c|}
\hline \multirow[t]{2}{*}{ Model } & \multicolumn{3}{|c|}{ Standardize Edilmemiş Katsayı Standardize Katsayı } & \multirow[b]{2}{*}{$\mathrm{t}$} & \multirow[t]{2}{*}{ Anlam Düzeyi } \\
\hline & B & $\begin{array}{c}\text { Std. } \\
\text { Hata }\end{array}$ & Beta & & \\
\hline Sabit & 2,406 & ,096 & & 25,013 & ,000 \\
\hline FoMO & 226 & ,036 & ,324 & 6,353 & ,000 \\
\hline \multicolumn{6}{|c|}{ Bağımlı Değişken: Sosyal Medya Tutumu } \\
\hline \multicolumn{3}{|c|}{ F Değeri: 40,356 } & & & \\
\hline \multicolumn{3}{|c|}{$\mathrm{R}=.324$} & 105 & & \\
\hline
\end{tabular}

Tablo 4'deki $F$ değeri 40,356 ve p değeri $0,00<0,05$ olduğundan oluşturulan regresyon modeli istatistiksel olarak anlamlıdır. Regresyon katsayılarının anlamlılığına işaret eden $t$ istatistiklerine $(t=6,353$ $\mathrm{p}=, 00<0,05$ ) göre; gelişmeleri kaçırma korkusunun sosyal medya tutumlarına etkisi istatistiksel olarak anlamlidir.

Değişkenler arasında pozitif yönlü ilişki $(\mathrm{r}=0,324)$ vardır. Bağımsız değiş̧kenin bağımlı değişkeni açıklama oranı olan $\mathrm{R}^{2}=0,105$ olarak hesaplanmıştır. Yani sosyal medya tutumlarındaki değişimlerin \% 10 'u FoMO düzeyi ile açıklanmakta ve FoMO düzeyindeki 1 birimlik artış sosyal medya tutumunu 0,226 birim artırmaktadır şeklinde yorumlanmaktadır.

Gelişmeleri kaçırma korkusunun sosyal medya tutumu alt boyutu olan sosyal yetkinlik ile arasındaki regresyon analizi sonuçları tablo 5 'te verilmiştir.

Tablo 5. FoMO İle Sosyal Yetkinlik Arasındaki Regresyon Analizi Sonuçları

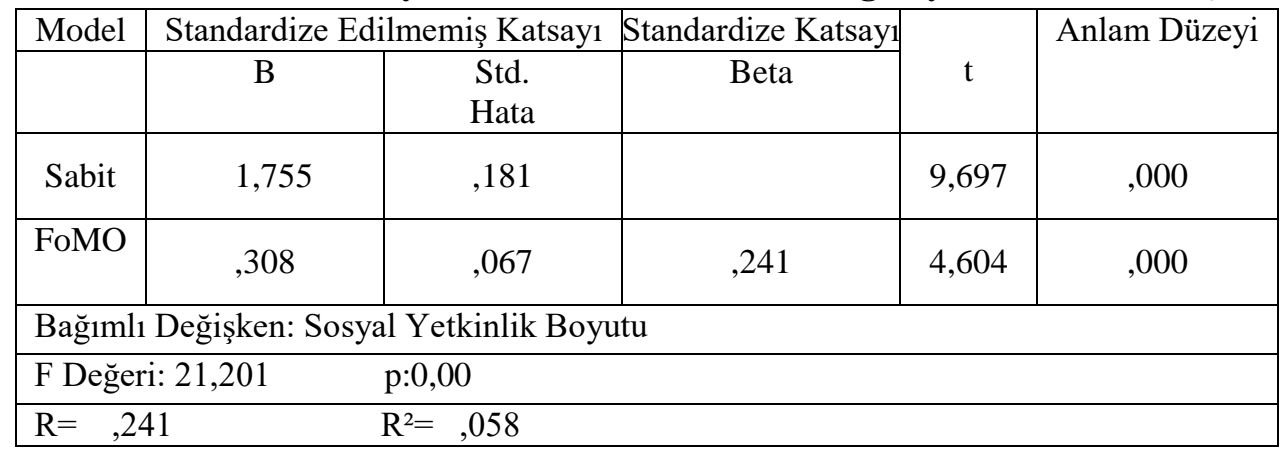

Tablo 5'deki $\mathrm{F}$ değeri 21,201 ve p değeri $0,00<0,05$ olduğundan oluşturulan regresyon modeli istatistiksel olarak anlamlıdır. regresyon katsayılarının anlamlılığına işaret eden $t$ istatistiklerine $(t=4,604$; $\mathrm{p}=, 00<0,05$ ) göre; FoMO' nun sosyal yetkinlik boyutuna etkisi istatistiksel olarak anlamlidır.

Değişkenler arasında pozitif yönlü ilişki $(\mathrm{R}=0,241)$ vardır. Bağımsız değişkenin bağımlı değişkeni açıklama oranı olan $\mathrm{R}^{2}=0,058$ olarak hesaplanmıştır. Yani sosyal yetkinlik boyutundaki değişimlerin \%058'i FoMO düzeyi ile açıklanmakta ve FoMO düzeyindeki 1 birimlik artış sosyal yetkinlik düzeyini 0,308 birim artırmaktadır şeklinde yorumlanmaktadır.

Gelişmeleri kaçırma korkusunun sosyal medya tutumu alt boyutu olan paylaşım ihtiyacı ile arasındaki regresyon analizi sonuçları tablo 6' da verilmiştir. 
Tablo 6. FoMO İle Paylaşım İhtiyacı Arasındaki Regresyon Analizi Sonuçları

\begin{tabular}{|c|c|c|c|c|c|}
\hline Model & Standardize & iş Kat & Standardize Katsayı & & Anlam Düzeyi \\
\hline & B & $\begin{array}{l}\text { Std. } \\
\text { Hata }\end{array}$ & Beta & $\mathrm{t}$ & \\
\hline Sabit & 2,377 &, 159 & & 14,963 & ,000 \\
\hline FoMO & 335 & ,059 & 294 & 5,708 & , 000 \\
\hline Bağıml & eğişken: Pa & iyac1 & tu & & \\
\hline F Değe & i: 32,584 & & & & \\
\hline $\mathrm{R}=, 29$ & & & ,087 & & \\
\hline
\end{tabular}

Tablo 6'daki $\mathrm{F}$ değeri 32,584 ve $\mathrm{p}$ değeri $0,00<0,05$ olduğundan oluşturulan regresyon modeli istatistiksel olarak anlamlıdır. Regresyon katsayılarının anlamlılığına işaret eden $\mathrm{t}$ istatistiklerine $(\mathrm{t}=5,708$; $\mathrm{p}=, 00<0,05$ ) göre; FoMO'nun paylaşım ihtiyacı boyutuna etkisi istatistiksel olarak anlamlıdır.

Değişkenler arasında pozitif yönlü ilişki $(\mathrm{R}=0,294)$ vardır. Bağımsız değişkenin bağımlı değişkeni açıklama oranı olan $\mathrm{R}^{2}=, 087$ olarak hesaplanmıştır. Yani paylaşım ihtiyacı boyutundaki değişimlerin \%087'si FoMO düzeyi ile açıklanmakta ve FoMO düzeyindeki 1 birimlik artış paylaşım ihtiyacı düzeyini 0,335 birim artırmaktadır şeklinde yorumlanmaktadır.

Gelişmeleri kaçırma korkusunun sosyal medya tutumu alt boyutu olan öğretim görevlileriyle iletişim boyutu ile arasındaki regresyon analizi sonuçları tablo 7' de verilmiş̧ir.

Tablo 7. FoMO İle Öğretim Görevlileri İle İletişim Arasındaki Regresyon Analizi Sonuçları

\begin{tabular}{|c|c|c|c|c|c|}
\hline Model & \multicolumn{2}{|c|}{ Standardize Edilmemiş Katsay1 } & Standardize Katsayı & \multirow{2}{*}{ t } & Anlam Düzeyi \\
\hline Sabit & $\mathrm{B}$ & $\begin{array}{c}\text { Std. } \\
\text { Hata }\end{array}$ & Beta & 8,151 & \multirow{2}{*}{, 000} \\
\hline FoMO &, 214 & & 5,091 &, 000 \\
\hline Bağımlı Değişken: Öğretim Görevlileri İle İletişim &, 265 & \\
\hline F Değeri: 25,921 &, 079 & $\mathrm{p}: 0,00$ & \\
\hline $\mathrm{R}=, 265$ & $\mathrm{R}^{2}=, 070$ \\
\hline
\end{tabular}

Tablo 7'deki $\mathrm{F}$ değeri 25,921 ve $\mathrm{p}$ değeri $0,00<0,05$ olduğundan oluşturulan regresyon modeli istatistiksel olarak anlamlıdır. regresyon katsayılarının anlamlılığına işaret eden $t$ istatistiklerine $(\mathrm{t}=5,091$; $\mathrm{p}=, 00<0,05$ ) göre; FoMO'nun öğretim görevlileri ile iletişim boyutuna etkisi istatistiksel olarak anlamlıdır.

Değişkenler arasında pozitif yönlü ilişki $(\mathrm{R}=0,265)$ vardır. Bağımsız değişkenin bağımlı değişkeni açıklama oranı olan $\mathrm{R}^{2}=, 070$ olarak hesaplanmıştır. Yani öğretim görevlileri ile iletişim boyutundaki değişimlerin \%070'i FoMO düzeyi ile açıklanmakta ve FoMO düzeyindeki 1 birimlik artış öğretim görevlileri ile iletişim düzeyini 0,403 birim artırmaktadır şeklinde yorumlanmaktadır.

Gelişmeleri kaçırma korkusunun sosyal medya tutumu alt boyutu olan sosyal izolasyon ile arasındaki regresyon analizi sonuçları tablo 8' de verilmiştir.

Tablo 8. FoMO İle Sosyal İzolasyon Arasındaki Regresyon Analizi Sonuçları

\begin{tabular}{|c|c|c|c|c|c|}
\hline Model & Standardize Edilmemiş Katsay 1 & Standardize Katsayı & \multirow{2}{*}{ Anlam Düzeyi } & \\
\hline & $\mathrm{B}$ & $\begin{array}{c}\text { Std. } \\
\text { Hata }\end{array}$ & Beta & & \multirow{2}{*}{000} \\
\hline Sabit & 3,426 &, 120 & & 28,633 &, 041 \\
\hline FoMO &,- 091 &, 044 &,- 110 & $-2,049$ & \\
\hline \multicolumn{5}{|l|}{ Bağımlı Değişken: Sosyal İzolasyon Boyutu } \\
\hline \multicolumn{5}{|l|}{ F Değeri: 4,200 0,041} \\
\hline $\mathrm{R}=, 110$ & $\mathrm{R}^{2}=, 012$ \\
\hline
\end{tabular}

Selçuk Üniversitesi Sosyal Bilimler Meslek Yüksekokulu Dergisi, Yıl: 2019 Cilt: 22 Sayı:2 
Tablo 8'deki f değeri 4,200 ve $\mathrm{p}$ değeri $\mathrm{p}=, 04<0,05$ olduğundan oluşturulan regresyon modeli istatistiksel olarak anlamlıdır. Regresyon katsayılarının anlamlılığına işaret eden $\mathrm{t}$ istatistiklerine ( $\mathrm{t}=-2,049$; $\mathrm{p}=, 04<0,05$ ) göre; FoMO'nun sosyal izolasyon boyutuna etkisi istatistiksel olarak anlamlıdır.

Değişkenler arasında negatif yönlü ilişki $(\mathrm{R}=0,110)$ vardır. Bağımsız değişkenin bağımlı değişkeni açıklama oranı olan $\mathrm{R}^{2}=, 012$ olarak hesaplanmıştır. Yani sosyal izolasyon boyutundaki değişimlerin \%012'i FoMO düzeyi ile açıklanmakta ve FoMO düzeyindeki 1 birimlik artış sosyal izolasyon düzeyini 0,091 birim azaltmaktadır şeklinde yorumlanmaktadır.

\section{TARTIŞMA VE SONUÇ}

Karamanoğlu MehmetBey Üniversitesi, Sağlık Bilimleri Fakültesi’nde okuyan 450 öğrencinin gelişmeleri kaçırma korkularının sosyal medya tutumlarını nasıl etkilediğini araştırdığımız bu çalışmada öğrencilerin gelişmeleri kaçırma korkularının sosyal medya tutumlarını etkilediği ortaya konulmuştur.

Araştırmamızda gelişmeleri kaçırma korkusu (FoMO) ile sosyal medya tutumları arasında yapılan korelasyon ve regresyon analizlerinde istatistiksel olarak anlamlı pozitif ilişki bulgulanmıştır. Çalışma bulgumuz literatür ile uyumlu bulunmuştur (Oberst, 2017; Blackwell, 2017; Alt, 2017; Beyens, 2016; Alt, 2015; Przybylskivd., 2013)Tanrikulu (2018) lise ve üniversite öğrencileri örneklemi kullanarak yaptı̆̆1 çalışmasında FoMO ve sosyal medya bağımlılığı arasında pozitif ilişki bulgulamıştır. 17 yaş üstü 5280 sosyal medya kullanıcısı ile yaptığı çalışmasında Oberstvd. (2017) FoMO ile sosyal medya bağımlılığ1 arasında yine pozitif anlamlı ilişki bulgulamıştır. "Dışa Dönüklük, Nevrotiklik, Bağlanma Tarzı ve Sosyal Medya Kullanımı ve Bağımlılığının Yordayıcıları Olarak Yoksun Olma Korkusu” başlıklı çalışmasında Blackwell vd. (2017) 17-49 yaş arasında 207 katılımcı ile yaptıkları çalışmalarında yine FoMO ile sosyal medya bağımlılığı arasında pozitif anlamlı ilişki bulgulamışlardır. Daha önceki çalışma sonuçlarına ve bu çalışma bulgularına dayanarak gelişmeleri kaçırma korkuları yüksek olan bireylerde sosyal medya bağımlılı̆̆ının arttığı söylenebilir.

Araştırmamızda sosyal medya tutumlarının alt boyutları ile FoMO arasındaki ilişki araştırılmıştır. İlk olarak FoMO ile sosyal medya tutumu alt boyutlarından sosyal yetkinlik boyutu ilişkisi araştırılmışır. Korelasyon analizi sonucunda FoMO ile sosyal yetkinlik arasında pozitif anlamlı ve çok zayıf düzey ilişki $(r=0,241 ; \mathrm{p}<0,01)$ bulgulanmış, regresyon analizi ile de FoMO'nun sosyal yetkinliği açıklama oranı $\mathrm{R}^{2}=$ 0,058 olarak bulgulanmıştır. FoMO düzeyindeki 1 birimlik artış sosyal yetkinlik düzeyini 0,308 birim artırmaktadır şeklinde yorumlanmıştır. Literatürde benzer bir çalışma Altınay Bor (2018) tarafından yapılmış.Ruppel ve Burke (2014) çalışmalarında sosyal yetkinliği yüksek olan bireylerin daha fazla Facebook iletişimi kullandığını ifade etmişlerdir. Sosyal medya kişilerin ayrı birer kişilik oluşturmasına izin vermesi açısından çok önemli bir platformdur ve bu durumun kişilerin sosyal medya bağımlılığını artıran bir sebep olması kuvvetle muhtemeldir. Bu nedenle yüksek düzeyde kaçırma korkusu olan bireylerde sosyal yetkinlik hissinin yüksekliği muhtemel bir durumdur. Bu bağlamda FoMO düzeyi yüksek olan kişilerin yüksek sosyal yetkinliğe sahip oldukları söylenebilir.

FoMO ile sosyal medya tutumu alt boyutlarından paylaşım ihtiyacı boyutu ilişkisi araştırılmıştır. Korelasyon analizi sonucunda FoMO ile paylaşım ihtiyacı arasında pozitif anlamlı ve zayıf düzey ilişki $(r=0 ; 294 \mathrm{p}<0,01)$, bulgulanmış, regresyon analizi ile de FoMO'nun paylaşım ihtiyacını açıklama oranı $\mathrm{R}^{2}=$ 0,087 olarak bulgulanmıştır. FoMO düzeyindeki 1 birimlik artış paylaşım ihtiyacını düzeyini 0,335 birim artırmaktadır şeklinde yorumlanmıştır. Altınay Bor (2018) çalışmasında FoMO ile paylaşım ihtiyacı arasında negatif ilişki bulgulamış ve FoMO düzeyi yüksek olan kişilerin sosyal medyada paylaşım yapmaktan çok takip etme davranışı sergiledikleri şeklinde yorumlamıştır. Sosyal medyayı devamlı etme ve paylaşım yapma isteği FoMO hastalığının hem belirtisi (Akgül, 2016) hem de hastalığı tetikleyen bir etmen (Tarhan, 2015) olarak karşımıza çıkmaktadır. Bu durumda gelişmeleri kaçırma korkusu yaşayan bir bireyin paylaşım yapması hastalığın gelişmesinde ve devam etmesinde temel etkenler arasında sayabiliriz. Aynı zamanda kişinin yarattığ 1 farklı kimliği devam ettirmek ve farklı kimliğinin beğenilmesi ihtiyacı ancak sosyal medya paylaşımı yaparak tatmin edilebilmektedir. Gelişmeleri kaçırma korkusu olan bireyler yalnızlık duygusu ile başa çıkabilmek için, sevgi ve şefkati sosyal ağlardaki paylaşımlarla tamamlamaya çalışmaktadırlar (Yıldırım ve Kişioğlu; 2018). İki kavram arasında net bir şekilde neden sonuç ilişkisi olmasa da gelişmeleri kaçırma korkusu yaşayan bireylerin daha yüksek sosyal medya paylaşımı yapması muhtemel gözükmektedir.

FoMO ile sosyal medya tutumu alt boyutlarından öğretim görevlileriyle ilişki boyutu ilişkisi araştırılmıştır. Korelasyon analizi sonucunda FoMO ile öğretim görevlileriyle ilişki boyutu arasında zayıf 
düzey ilişki $(r=0,294 ; \mathrm{p}<0,01)$ bulgulanmış, regresyon analizi ile de FoMO'nun öğretim görevlileriyle iletişim düzeyini açıklama oranı $\mathrm{R}^{2}=0,070$ olarak bulgulanmıştır. FoMO düzeyindeki 1 birimlik artış öğretim görevlileriyle iletişim düzeyini 0,403 birim artırmaktadır şeklinde yorumlanmıştır. Altınay Bor (2018) çalışmasında FoMO ile öğretim görevlileriyle iletişim arasında negatif ilişki bulgulamıştır. Gelişmeleri kaçırma korkusu yüksek olan bireyler başkaları tarafından beğenilme isteği fazla olan kişilerdir (Yıldırır, 2016) ve FoMOsürekli beğenilme isteği ile karakterizedir (Karabulut, 2015). Öğrenciler için mentor görevi gören öğretim görevlileri tarafindan takdir edilmesi öğrencileri mutlu eden bir durumdur. Öğrencinin sosyal medya üzerinden yaptığı bir paylaşımın öğretim görevlisi tarafından beğenilmesi, öğrencinin mutlu olmasına neden olabilmektedir. Çünkü sosyal medyada yapılan paylaşımların beğeni oranının düşük olması insanların mutsuzluğuna yol açabilmektedir (Çiftci, 2018). Bu bağlamda bireyler sosyal medyada beğenilmesi özellikle rol model aldıkları bireyler tarafından beğenilmesi sosyal medya bağımlılıklarını artırabilecek bir faktör olarak görmek mümkündür. Bu bağlamda gelişmeleri kaçırma korkusu yaşayan öğrencilerin öğretim görevlileri ile sosyal medya üzerinden kurdukları iletişimde gelişmeleri kaçırma korkusu yaşamaları beklenen bir sonuçtur.

FoMO ile sosyal medya tutumu alt boyutlarından sosyal izolasyonboyutu ilişkisi araştırılmıştır. Korelasyon analizi sonucunda FoMO ile sosyal izolasyon arasında negatif anlamlı ve çok zayıf düzey ilişki $(r=-0,110 ; \mathrm{p}<0,01)$ bulgulanmış, regresyon analizi ile de FoMO'nun sosyal izolasyon boyutunu açiklama oranı $\mathrm{R}^{2}=0,012$ olarak bulgulanmıştır. FoMO düzeyindeki 1 birimlik artış paylaşım ihtiyacını düzeyini 0,091 birimazaltmaktadır şeklinde yorumlanmıştır. Sosyal medyada vakit geçirme artıkça artan depresyon oranının nedenlerinden birinin sosyalizolasyon olabileceği düşünülmektedir (Şahin, 2018). Çünkü telefonlar kullanıldıkları sürece bireye geçici mutluluk sağlayan cihazlardır. Kullanılmadıkları zaman ise insan iletişimden farklı olarak insanların mutsuzluluğuna yol açabilmektedirler. Aşırı telefon kullanımı insanları insani iletişimden yoksun bırakarak toplumdan izole olmasına neden olmaktadır (Ayaz, 2018). Dolayısıyla özellikle yüksek düzeyde gelişmeleri kaçırma korkusu yaşayan kişilerin sosyal medyada daha fazla vakit geçirmeleri toplumdan izole olmalarına yol açacaktır. Ancak insanların sosyal medyada yaratılan sanal ortamın gerçekliğine inanmaları ve etraflarına örülen demir kafeslerin farkına varmamaları sosyal yönden izole olduklarının farkına varmamalarına neden olabilmektedir (Ünlü, 2018). Ankete cevap veren öğrencilerinde bu bağlamda toplumdan izole olduklarının farkına varmamaları ve izole olmadıkları yönünde cevap vermeleri gelişmeleri kaçırma korkuları ile sosyal izolasyonları arasında negatif bir ilişkinin ortaya çıkmasına neden olması muhtemeldir.

Öğrencilerin gelişmeleri kaçırma korkularının sosyal medya tutumları ile ilişkisini araştıran bu çalışmada beklenildiği gibi iki kavram birbirleriyle ilişkili çıkmıştır. FoMO'nun en yüksek etkilediği sosyal medya tutum boyut öğretim görevlileriyle iletişim boyutu olarak bulgulanırken, paylaşım ihtiyacı ve sosyal yetkinlik boyutları ikinci ve üçüncü en yüksek etki bulgulanan boyutlar olarak tespit edilmiştir. Literatürde özelikle FoMO ile ilgili çalışmaların son derece yetersiz olduğu ve sosyal medya tutumları ile ilgili çalışmaların ise daha çok bireysel özelliklerle ilişkilendirilen çalışmalar olduğu göze çarpmıştır. İki kavram arasındaki ilişkinin araştırıldığı çalışma sayısı son derece yetersizdir. Ayrıca sınırlı sayıdaki bulunan çalışmalar arasında sosyal medya tutumları genellikle bir bütün olarak ele alınmış ve alt boyut olarak irdelemenin yapıldığı tek bir çalışmaya rastlanmıştır. Altınay Bor (2018) tarafından yapılan bu tez çalışmada ise örneklem ortaöğretim öğrencileridir. Dolayısıyla bu çalışma üniversite öğrencileri örneklemini kullandığı ve sosyal medya tutumlarını alt boyut bazında incelemesi nedeniyle özgün niteliktedir ve literatüre yüksek düzeyde katkı sağlayacağı düşünülmektedir.

Ancak sonuçların sadece araştırma kapsamına alınan grubu temsil ettiği ve bu bağlamda genelleme yapılırken dikkatli olunması önerilmektedir. İki kavram ile ilgili çalışmaların farklı değişkenlerle ilişkisinin araştırılmasının literatüre katkı sağlayacağı düşünülmektedir. 


\section{KAYNAKÇA}

Ada, Serkan ve Abul, Akın (2014) "İşletmelerde Sosyal Medya Kullanımı: İşletme Bölümü Öğrencilerinin Algıları Üzerine Bir Araştırma". Kahramanmaraş Sütçü İmam Üniversitesi, İktisadi ve İdari Bilimler Fakültesi Dergisi, 4(1), s.316-327.

Akgül, Ömer (2016) "FoMO (Fear Of Missing Out)", Erişim Adresi: http://ruhsagligidernegi.org /fomo-fear-ofmissing-out/ Erişim Tarih:17.07.2019.

Alt, Dorit (2017). "Students' Social Media Engagement And Fear Of Missing Out (Fomo) İn A Diverse Classroom". Journal of Computing in Higher Education, 29(2), s.388-410.

Altınay Bor, Hilal (2018). "Ergenlerde Sosyal Medyaya Yönelik Tutum, Sosyal Medya Kullanımında Gelişmeleri Kaçırma Korkusu ve Sosyal Kaygı Arasındaki İlişkiler", Yüksek Lisans Tezi, İstanbul Üniversitesi, Eğitim Bilimleri Enstitüsü, İstanbul.

Ayaz, M.Bayram (2018) “Fomo Olduğunuzu Nasıl Anlarsınız?” Erişim Adresi: http://www.cumhuriyet.com.tr/ haber/bilimveteknoloji/953795/FOMOoldugunuzunasilanlarsiniz.html. Erişim Tarihi:17.07.2019.

Beyens, Ine, Eline Frison, and Steven Eggermont (2016) "I don't want to miss a thing": Adolescents' fear of missing out and its relationship to adolescents' social needs, Facebook use, and Facebook related stress. Computers in Human Behavior, s.64, 1-8.

Blackwell, David, Leaman, Carriel, Tramposch, Rose, Osborne, Ciera, \& Liss, Miriam (2017) "Extraversion, Neuroticism, Attachment Style And Fear Of Missing Out As Predictors Of Social Media Use And Addiction", Personality And Individual Differences, 116, s.69-72.

Boyd, Danah M., and Ellison Nicole B. (2007) "Social Network Sites: Definition, History, and Scholarship", Journal of Computer-Mediated Communication, 13(1), s.210-230.

Büyükşener, Ercüment (2009). “Türkiye'de Sosyal Ağların Yeri ve Sosyal Medyaya Bakış”, XIV. Türkiye'de İnternet Konferans1 Bildirileri, Bilgi Üniversitesi, s.12-13.

Konsensus Araştırma Şirketi (2011),"Çocukların Sosyal Paylaşım Sitelerini Kullanım Alı̧̧kanlıkları Araştırması Raporu” Erişim Adresi: https://docplayer.biz.tr/7446995-Cocuklarin-sosyal-paylasim-sitelerini-kullanimaliskanliklari-arastirma si-raporu.html. Erișim Tarihi:18.07.2019.

D’Souza, Quentin, (2006) Web 2.0 İdeas For Educators, A Guideto RSS And More. Version 2.0, In Meeting of the K12. Retrievedfromhttp://www.teachinghacks.com/audio/100ideasWeb2educa tors. pdf.

Edosomwan, Simeon, Prakasan, Sitalaskshmi Kalangot, Kouame, Doriane, Watson, Jonelle, \&Seymour, Tom (2011). "The History Of Social Media And İts İmpact On Business", Journal of Applied Management and Entrepreneurship, 16(3), s.79-91.

Erdoğan, Pınar ve İraz, Rıfat (2019) “ Örgütsel Vatandaşlık, Örgütsel Sinizm Ve Tükenmişliğe Pozitif Psikolojik Sermaye Etkisi” Eğitim Yayınevi, Konya

Eren, Veysel ve Aydın, Abdullah (2014) "Sosyal Medyanın Kamuoyu Oluşturmadaki Rolü ve Muhtemel Riskler”, Karamanoğlu Mehmetbey Üniversitesi, Sosyal ve Ekonomik Araştırmalar Dergisi, 2014(3), 197-205.

Ergenç, Ayfer (2011) “Web 2.0 ve Sanal Sosyalleşme: Facebook Örneği”, Yüksek Lisans Tezi, Maltepe Üniversitesi, Sosyal Bilimler Enstitüsü, İstanbul .

Gökler, Mehmet Enes, Aydın, Reşat, Ünal, Egemen ve Metintaş, Selma (2016) “ Sosyal Ortamlarda Gelişmeleri Kaçırma Korkusu Öllçeğinin Türkçe Sürümünün Geçerlilik Ve Güvenilirliğinin Değerlendirilmesi” Anadolu Psikiyatri Dergisi, 17(1), s.52-59.

Hazar, Murat (2011). "Sosyal Medya Bağımlılı̆̆ı-Bir Alan Çalışması”, İletişim Kuram ve Araştırma Dergisi, 32(1), s.151-176.

Işıktaş, Serdal (2016) "Meslek Yüksekokulu Öğrencilerinin Sosyal Medya Kullanımına Yönelik Tutumlarının Değerlendirilmesi”, Akademik Sosyal Araştırmalar Dergisi, 35(4), s.565-575.

Global Digital Report (2019).Erişim Adresi: https://wearesocial.com/global-digital-report-2019.Erișim Tarihi:01.11. 2019.

Gurbetoğlu, Ali (2018) "Bilimsel Araştırma Yöntemleri”, Erişim Adresi: http://agurbetoglu.com/files/2-\%20ARA \%C 5\% 9ETIRMA\%20\%20T\%C3\%9CRLER\%C4\%B0.pdf, E.T.19.09.2019 
Karabulut, Gamze (2015) “Bunları Yapıyorsanız FOMO Hastası Olabilirsiniz" Erişim Adresi: http://www.hurriyet. com.tr/kelebek/saglik/bunlari-yapiyorsaniz-fomo-hastasi-olabilirsiniz-40027841, E.T.17.07.2019.

Kayış, Aliye(2010) “Güvenilirlik Analizi”, (Editör: Şeref Kalaycı) SPSS Uygulamalı Çok Değişkenli İstatistik Teknikleri.(5. Baskı). Ankara: Asil Yayın Dağıtım Ltd. Şti. s:403-426.

Li, Charlene, Bernoff, Josh , Pflaum, Cynthia, \&Glass, Sarah (2007) "How Consumers Use Social Networks Sarah" Forrester Research. June, 21, 2007.

Mayfield, Antony (2008), "What is Social Media", iCrossing, e-book, s. 6. Erişim Adresi:http://www.icrossing. co.uk/fileadmin/uploads /eBooks/What_is_Social_Media_iCrossing_ebook.pdf, ErişimTarihi:09.07.20 19.

Merchant, Nilofer (2013). "What We Talk About When We Talk About "Social”. Erişim Adresi: https://hbr.org/2013/02/what-we-talk-about-when-we-tal. E.T.18.07.2019

Newson, Alex, Houghton, Deryck and Patten, Justin (2008) “Blogging And Other Social Media: Exploiting The Technology And Protecting The Enterprise". Gower Publishing, Ltd.

Otrar, Mustafa ve Argın, F. Süleyman (2015). Öğrencilerin Sosyal Medyaya İlişkin Tutumlarını Belirlemeye Yönelik Bir Ölçek Geliştirme Çalışması. Eğitim ve Öğretim Araştırmaları Dergisi, 4(1), s.391-403.

Oberst, U., Wegmann, E., Stodt, B., Brand, M., \& Chamarro, A. (2017). "Negative Consequences From Heavy Social Networking İn Adolescents: The Mediating Role Of Fear Of Missing Out”, Journal of adolescence, 55, s.51-60.

Przybylski, A. K., Murayama, K., DeHaan, C. R., \&Gladwell, V. (2013). "Motivational, Emotional, Andbehavioralcorrelates Of Fear Of Missingout", Computers in Human Behavior, 29(4), s.1841-1848.

Ruppel, E. K.,\&Burke, T. J. (2014). Complementary Channel Use And The Role Of Social Competence. Journal of Computer-Mediated Communication, 20(1), s.37-51.

Sayın, Ahmet Alper, Muhammet Volkan Armağan, and İsmail Karakulle (2017) "Sosyal Medyanın Tüketici Davranışları Etkileri Üzerine Üniversite Öğrencilerine Yönelik Bir Araştırma." Akademik Sosyal Araştırmalar Dergisi. Y11 5, s.437-452.

Smock, A. D., Ellison, N. B., Lampe, C., \& Wohn, D. Y. (2011). "Facebook As A Toolkit: A Uses And Gratification Approach To Unbundling Feature Use". Computers in Human Behavior, 27(6), p.2322-2329.

Sungur, O. (2010). "Korelasyon Analizi”. (Editör: Şeref Kalaycı) SPSS Uygulamalı Çok Değişkenli İstatistik Teknikleri.(5. Baskı). Ankara: Asil Yayın Dağıtım Ltd. Şti.

Şahin, A. (2018). FoMO nedir? Erişim Adresi: https://www.cnnturk. com/teknoloji/fomo-nedir, E.T.18.07. 2019.

Tanrıkulu, G.(2018). Güncellenmeliyim": Sosyal Ortamlarda Gelişmeleri Kaçırma Korkusu Ve Bunun Ergen Ve Genç Yetişkinlerdeki Sosyal Medya Bağımlılığı Boyutlarına Yordayıcı Olarak Öncülleri. Yüksek Lisans Tezi, TED Üniversitesi, lisansüstü Programlar Enstitüsü, Ankara.

Tarhan, N. (2015). FOMO sosyal medya kullanıcıları arasında oldukça yaygın. Erişim Adresi: (Https://Www.Ntv. Com.Tr/Teknoloji/Fomo-Sosyal-Medya-Kullanicilari-Arasinda-Oldukca-Yaygin,Mn0trmb4quap1lz-Qg2hvg E.T.17.07.2019.

TheMerriam-Webster sözlüğü https://www.merriam-webster.com/ dictionary/social\%20media

Ulaştıran, T. (2017) “Çağımızın Salgını FOMO: Pazarlama Dünyasındaki Başarısının Ardındaki Gerçekler”. Erişim Adresi: https://pazarlamasyon. com/ cagimizin-salgini-FoMO-pazarlama-dunyasindaki-basarisinin-ardindakigercekler/ E.T.13.06.2019

Ünlü, F. (2018). “Orta Yaş Üstü Bireylerde Sosyal Medya Bağımlılığı ve Sosyal İzolasyon”. PESA Uluslararası Sosyal Araştırmalar Dergisi, 4(1), s.161-172.

Vural, Z.,\& Bat, M. (2010). "Yeni Bir İletişim Ortamı Olarak Sosyal Medya: Ege Üniversitesi İletişim Fakültesine Yönelik Bir Araştırma”. Journal of YasarUniversity, 5(20). s.3348-3382

Yazıcıŏ̆lu, Y. Ve Erdoğan S.(2014). “SPSS Uygulamalı Bilimsel Araştırma Yöntemleri”. (4. Baskı) Ankara: Detay Yayınları.

Yeniçıktı, N. T. (2016) "Sosyal Medya Kullanım Motivasyonları: Facebook Ve Twitter Kullanıcıları Üzerine Kullanımlar ve Doyumlar Araştırması” . Doktora Tezi. Selçuk Üniversitesi, Sosyal Bilimler Enstitüsü, Konya

Yıldırım, S., Kişioğlu, A. (2018). “Teknolojinin Getirdiği Yeni Hastalıklar: Nomofobi, Netlessfobi, FOMO”. SDÜ Tıp Fakültesi Dergisi, 25(4), p.473-480. 
Yıldırır, Ö. (2016). "Sosyal Medya Hastalığı: Fomo Nedir”. Erişim Adresi: https://www.ilimvemedeniyet.com/sosyalmedya-hastaligi-fomo-nedir.html E.T.17.07.2019.

Wenting, X. (2019). "Discussion On Strategies Of Crisis Management İn University Under The Back Ground Of Social Media". ScienceJournal of Education, 7(1), 14.

Wiesner, L. (2017). "Fighting FoMO: A Study On İmplications For Solving The Phenomenon Of The Fear Of Missingout" (Master'sthesis, University of Twente).

https://en.oxforddictionaries.com/definition/FoMO E.T.15.06.2019 